\title{
Politics in History Education in Hong Kong: Towards Critical Political Education
}

\author{
Cong Lin and Liz Jackson*
}

\begin{abstract}
The relationship between history education and political education in Asian societies is an underexplored topic. Politics have deeply shaped the development of history education in Hong Kong, as in many other societies around the world. Hong Kong history education reforms have been criticized for providing a new form of national political education. This study examines how politic education can be found in the Hong Kong history curriculum as 'latent content'. To do so, it provides a qualitative content analysis of all textual data used in 'Chinese history' and 'history' textbooks in secondary schools in Hong Kong which discuss or portray political content, focusing particularly on the themes of identity shaping and assimilation. Before focusing on the Hong Kong situation, this paper first explores how history education is a political topic in general. Then Hong Kong's complicated political legacy is described in relation to one of the unique features of history education there: the concurrence of two subjects, 'history' and 'Chinese history'. Current debates about the reform of history education in Hong Kong and the limitations of current history education in Hong Kong are examined in the next part, using data from textbooks. Our analysis shows that 1) national identity is prioritized over local identity in the textbooks, and 2) the textbooks mainly reflect a Mainland-based majority perspective and justify assimilation in history, resulting in a lack of recognition of the many different minority groups of Mainland China, of which Hong Kong people may see themselves as part. Based on the analysis, we argue that history education in Hong Kong provides a narrow political education that can impede some crucial education goals in Hong Kong.
\end{abstract}

Keywords: Politics; critical political education; history education; textbooks; Hong Kong

* The University of Hong Kong

Liz JACKSON e-mail: lizjackson@hku.hk,

Cong LIN e-mail: u3004761@connect.hku.hk 


\section{Introduction}

Politics has deeply shaped history education in Hong Kong. During the colonial period, historical ties between Hong Kong and Mainland China were partly severed, and history education was characterized by "depoliticization". Educational policymakers mandated that teachers not engage students in any explicit political discussions or activities, against the British Empire, or for (or against) any other political groups, particularly those on the Mainland (Fairbrother, 2003; Lin \& Jackson, 2019a; Vickers, 2005). After the handover, history education was used in part to reconstruct political relations between Hong Kong, Mainland China, and western countries. The history curriculum has particularly changed to emphasise and promote a positive relationship between Hong Kong and China. Progressively, content has been added to history education to enhance positive views and feelings of affection and kinship in Hong Kong students toward Mainland China (Fairbrother, 2003; Vickers, 2005; Jackson, 2014b). History education (especially Chinese history) in Hong Kong has been criticised since then for providing a nationalist political education.

Few researchers have focused on the relationship between history education and political education in Asian societies, and particularly on the extent to which political education is or is not compatible with history education, urgent questions in Hong Kong today. This article aims to help fill this gap by examining the content of textbooks in 'Chinese History' and 'History' in secondary schools in Hong Kong. Using qualitative discourse analysis, this study examines the political content in the textbooks with a focus on 'latent content' (Fraenkel \& Wallen, 2015). Before focusing on the Hong Kong situation, the paper explores the political qualities of history education more generally. Next, current debates about the reform of history education in Hong Kong are explored. Then the paper provides an analysis of the political content of Hong Kong history textbooks. Based on the analysis, we find that history education in Hong Kong provides a narrow form of political education which can impede some crucial education goals in Hong Kong. In the last section, we elaborate on the need for critical political education in Hong Kong, and how history education there could be reconceptualised and revised by implication.

\section{Politics And History Education}

History education, as a bridge that connects past, present, and future, is interlaced with politics, especially as historical understanding entails a view of power relations. As Kan (2007) notes, "[o]f all the school subjects, history may be the most politically sensitive, and the one which most reflects the culture and politics of a society; it is a legitimating phenomenon serving to define national identity and ideology, and to contribute to nation-building" (pp.1-2). Generally, history education can serve three main political purposes. First, it can serve to unite diverse people at different levels in terms of their shared history: the shared history of national citizens in a particular country (national level) and the shared history of human beings (global level). Cosmopolitan thinkers emphasize the latter, while many others focus on the former. However, both perspectives are undergirded by the view that politics has an important place in history education.

It may be dangerous to focus on national history while neglecting global history, as this 
can leave the door open for national and partisan politics and related private parties to revise or even control the history discourse to serve their own interests (e.g., dividing the world and the nation, arousing international conflicts) (Lin \& Jackson, 2019b). This is a concern expressed by Sen (2006) as well as Barton and Levstik (2004): "when we link ourselves to one community, we often cut ourselves off from others, sometimes with ruinous consequences" (p. 46). Yet we also cannot assume that different countries agree on what is counted as 'fact'. For instance, Japan and China may have opposite 'facts' and interpretations about the same event in history textbooks. This means one cannot overlook the complicated situation of conflicts and substantive differences in perspective in relation to international relations and global politics, which can impact the shape and tone given to history education.

Second, history education is often used to maintain and strengthen the current social structure and as a tool for socialization. When history education has purposes of this kind, the way things are (that is, the status quo) is treated as a natural part of linear historical progression. On the other hand, critically assessing history education implies consideration of who has written history, which history to focus on, and how to interpret it. In these respects, politics, money and power are involved, and play a key role in history education. Typically, those in power have the authority to write and rewrite history. For those who do not accept a priori the interests of those in government who have authority, this means that "students [are] inculcated into the dominant ways of looking at the world [instead of developing] truly democratic spaces within schools and the larger social order" (Down, 2004, p. 15). Such history education helps a nation justify its legitimacy.

Choosing the content of history education and how to interpret it also reflects debates among different political parties and social groups. For scholars of postcolonialism and poststructuralism, the social structure is unequal, exclusive, and unjust, and needs to improve. However, teaching content and interpreting history only to socialize students to obey existing rules and social norms differs from empowering them with the knowledge, skills, and values to participate in an autonomous and potentially critical way in democratic processes in society. History contents, discourse, narratives, and language are all thus seen as manifestations of power and the reinforcement of power (Green, 1986).

Third, history helps a person to construct his or her identity (Jackson, 2014a, p. 17). History education relates to one's social, political, and cultural identity. In this sense, "the historian's professional role is to uncover what has been perceived as self-evident in the conventional historical narrative and to focus on the study of discursive structures, their political uses and exploitations and the way in which they constitute identity" (Yogev, 2013, p. 634). As Korostelina (2008, p. 25) notes,

Teaching about history not only provides information about the collective past, it also develops the meanings of current situations and affairs, and plays the major role in the formation of the concepts of the society. The content of history in school curricula usually supports the legitimacy of regimes and the power of ruling parties, and it articulates their respective points of view and positions. Moreover, school history curricula promote basic values and beliefs and support a society's specific view of the history of conflicts, violence, and mistrust among ethnic and religious groups.

It is an illusion that history education could be value-free and only focus on facts. However, even if the involvement of politics in history education is inevitable, one can still delib- 
erate systematically how to reconcile political issues and aims within history education. To achieve alignment with broader education goals (as found in Hong Kong curriculum and policy statements, among others) of open-mindedness, mutual respect, critical thinking, and the appreciation of diversity and differences, we argue that history education should teach about controversial political issues, rather than concealing them. Teaching about controversial issues can help students see the holistic reality of pluralistic societies, learn to appreciate the differences among people, and better attain means to engage in dialogue with mutual respect and towards cooperation (Lin \& Jackson, 2019a). As Davies (2017) points out, with

the constant juxtaposition of past and future together with the skill set they acquire, students can envision themselves as in the middle of the transition. They are not just voyeurs, not just recipients of curriculum, but active learners using skills gained through curriculum for social change as well as individual progress. The past, for good or ill, is usable. All this of course relies on teachers who are happy and capable to tackle controversial issues (p. 348)

The political sphere, as part of the public sphere, is relevant to all members of society. It has a significant influence on each person's life, and the social life for the next generation. Political education cannot be neutral, while it may be regarded as crucial for the survival of society. Good members of society are cultivated by political education, while the definition of good members of society may depend in part on the political and cultural context. Any political decision is controversial, but can be a great resource for students to learn from. By implementing relevant pedagogical methods, such as topic-based inquiry and facilitation of in-class political debate, teachers can better help students understand the considerations behind the processes of making political decisions, and the various factors that influence political decision making. Such understanding is an asset for students and can also help the society become more open to diversity and inclusive toward all.

\section{Problematic Political Education? History Education In Hong Kong}

Educational leaders in Hong Kong, a self-identified cosmopolitan multicultural society, recommend that students learn how to live together in society with dignity, and cooperate to solve the problems all are facing. Given Hong Kong's political history, it has two history subjects today, 'History' and 'Chinese history'. In Hong Kong many see "Chinese history" as a tool for the Chinese government to pursue its political interests. However, it is not clear whether the situation of the "History" subject is different. Although both are offered concurrently in schools, "[s]ince not all junior secondary students will take History as one of their elective subjects in senior secondary education, junior secondary History is most likely the only chance for some students to learn History, especially world history" (CDC, 2016, p. 2). In this context, one might expect that the history subject has among its aims to cultivate critical global citizens, in contrast to the Chinese history subject. However, history education also pushes a national agenda. The latest Curriculum and Assessment Guide (Secondary 4-6), updated in November 2015, states that one of the aims of the curriculum is to enable students to cultivate "national consciousness" and "thus become rational and sensible members of...the nation" (CDC, 2015 p. 2). 
At the same time, the rationale of the history subject (Secondary 4-6) is described in the guidelines as follows:

The topics covered in the History curriculum are of general historical significance, appropriate for illustrating the basic terminology and concepts of history, relevant to the daily experiences of students, and conducive to mastering the skills of historical study. They are also likely to arouse interest in students studying the subject. Students will be provided with an opportunity to pursue a study that transcends the temporal, cultural and political boundaries of our world. (CDC, 2015, pp. 1-2)

The guidelines thus encourage "students to review and reflect on their viewpoints to arrive at balanced judgments. Upon completion of this course, students should have cultivated the values and attitudes that are the attributes of a responsible citizen" (CDC, 2015, p. 2). Similar statements can be found in History (Secondary 1-3) The Revised Curriculum First Draft (For Consultation).

However, current history subjects are content-driven and based on textbooks. Without effective teacher training, history teachers may be lacking the necessary knowledge, skills, and values for teaching controversial issues, which can hamper the goals of teaching history. Local teacher practice in the subjects (i.e., teaching to texts and tests) makes things worse: "[a] pparently the teacher talks for most of the lesson and the class just have to take notes or answer questions from a textbook" (McGuire, 2017). This does not encourage creative and critical thinking as stated in the rationale and aims of the subjects. Although few students take history in senior secondary education today, the subject is still required in junior secondary education, while Chinese history will soon be required for all Hong Kong students.

The Hong Kong government, partly in response to pressure from the Chinese government and pro-Beijing groups, formed a committee to review Chinese history textbooks in December 2013. At present, the two history subjects are under revision by the Hong Kong Education Bureau, an issue which has aroused vigorous debate about whether history education will transform into a new, narrow form of national political education. The close relationship between history education and politics in Hong Kong in this case was noted by Tanya Chan, a Hong Kong legislator, who described the fight over history education as the latest battle with Mainland China over how Hong Kong is to be governed (Schmitz, 2017). The latest revision of the syllabus stipulates that students in junior secondary school must spend $76 \%$ of total class time on political history, higher than the $65 \%$ stipulated in the first draft.

Some people fear that history education is being revised to serve political purposes, with the assumption that history was previously a neutral domain in the schools, but will now become a tool for political brainwashing for the Beijing government (Kwok, 2017; Pang, 2017; Schmitz, 2017). If the government falsifies history or omits some crucial negative events in Mainland China in order to attain an alleged common good, students may not develop an effective picture of important events in Chinese history. In this sense, they could be seduced into cultivating an increasingly national and pro-Beijing identity without fully understanding what such an identity means (Schmitz, 2017).

On the other hand, other people support the reform of history education, and argue that history education will not be an obstacle for the free growth of students in Hong Kong. A typical argument is given in the local press (SCMP, 2017): 
Nurturing our younger generation with a better understanding of history and a stronger sense of national identity is part of education. Our reunification with China after more than a century of colonial rule means there is a lot to catch up on. As long as the subject is taught in a comprehensive and unbiased manner, there is no reason to resist, be it national education or the learning of Chinese history.

The Hong Kong Chief Executive Carrie Lam has thus emphasised that cultivating citizens who are "socially responsible" and "equipped with a sense of national identity" is crucial for Hong Kong students to become global citizens with a nationally Chinese identity (Chiu \& Yeung, 2017). Hong Kong's pro-establishment politicians blame the shallow understanding of Mainland history among Hong Kong students (as well as the legacy of the historically "depoliticized" colonial curricula) for the emergence of separatist and other critical sentiments. Similarly, the Chinese government has blamed anti-Mainland sentiment and public movements (e.g. the Umbrella Movement) on a lack of understanding and appreciation for Chinese history. Therefore, some Beijing officials believe that teaching Chinese history should be reinforced with more emphasis put on nationalism. Based on our analysis, we argue that these concerns regarding history education intersect with a curriculum challenge, as neither Chinese History nor History textbooks provide a comprehensive picture, and both can become fuel to cultivate bias, confusion, and even skepticism among Hong Kong students.

\section{Method}

For this study, we used qualitative content analysis of all textual data in Chinese history and history textbooks discussing or portraying political content, with a particular focus on the themes of identity shaping and assimilation. As Chinese history textbooks in Hong Kong are written in Chinese, we translated relevant sections of texts for this article. The major data source is textbooks for junior (grades 7-9) Chinese history, junior history (grades 7-9), and senior history (grades 10-12). Current textbooks for this subject have been vetted and recommended by the Education Bureau Textbook Committee. 35 Chinese history textbooks including 8 different series were analyzed for this article. This is roughly half of the 87 existing textbooks from 1997-2017. However, with all textbooks following the 1997 guidelines, the content is quite similar in all texts. Additionally, 29 History textbooks including 8 different series were analyzed, which is roughly 40 percent of the 73 existing textbooks published between 1997-2017. A table with basic information about the textbooks analysed is provided as an appendix. Textbooks are understood to be reflective of widely held social values, and thus reveal a significant part of "latent" curricula: not necessarily a secret or "hidden" curriculum, but rather potentially incidental content, particularly when it comes to complicated political issues in society (Lin \& Jackson, 2019a). We focus on "latent" content (Fraenkel \& Wallen, 2015) here: not just the obvious presence of subject(s), but the meaning and context of references as a whole, which may or may not have been intended by the curriculum designers. 


\section{Analysis}

If all history education is political, then the real question is, with what purpose? In the Hong Kong Chinese history and history textbooks we found, first, a focus on national identity over local identity. As discussed previously, promoting a sense of national identity has arguably been the ultimate goal of teaching Chinese history in Hong Kong from a historical view. After 1997, Hong Kong history was added to the Chinese history syllabus for the first time. This was done to boost students' interest in Chinese history, by enhancing students' perceptions of Hong Kong as having been a part of China since ancient times. C. H. Tung, the former Chief Executive, expressed overtly at that time that "[w]e will incorporate the teaching of Chinese values in the school curriculum and provide more opportunities for students to learn about Chinese history and culture. This will foster a strong sense of Chinese identity in our students" (Kan \& Vickers, 2002, p. 74).

In the preface of a junior history textbook (grades 7-9), as an answer to the question "Why study history?", one response offered is "[t] deepen our sense of belonging [to Mainland China]" (Cheng \& Fung, 2011a, p. 9). Cultivating students' national identity and sense of attachment to Mainland China in place of Hong Kong is also emphasized in Chinese history textbooks. Nearly every junior Chinese history textbook's preface states that Hong Kong people are Chinese, and have a strong obligation to know the history of China and the Chinese nation, and to make their contribution to the development of China (Liang et al., 2011, p. iii; Tan et al, 2009, p. iv). In order to cultivate students' cultural identity as a part of China, students should "become useful persons with lofty ideals, culture, morality, and the ability to analyse and judge" (Du et al., 2012b, p. vi), enhance their "sense of belonging to Chinese nation, and their patriotism" (Du et al., 2012b, p. x), and "generate a sense of identity and sense of pride in China and the Chinese nation" (Liang et al., 2011, p. i). For this purpose, "improving our understanding of the culture of China and its history could help us cultivate emotion toward our country and nation, and could also deepen our sense of belonging to and identity as a part of our nation and country" ( $\mathrm{Li}, \mathrm{Xu}$ and $\mathrm{Fu}, 2012$, p. N/A). Other examples used in junior Chinese history textbooks help students "rethink the importance of national identity through the action of using private things to harm the public good" ( $\mathrm{Li}, \mathrm{Xu}$ and Fu, 2012, p. 167), and thus orient students' sense of loyalty to Mainland China.

The history textbooks are traditionally seen as reflecting a western and liberal perspective in contrast to Chinese history texts. Nonetheless, in these textbooks as well, national identity is prioritized over local identity, to strengthen students' sense of national identity toward Mainland China (especially in the sections on local history). One text in a junior history textbook raises the question "Do you know that people lived in Hong Kong as early as the Stone Age?" (Cheng \& Fung, 2011a, p. 38), and adds that "[s]tarting from 214 BC, more and more mainland people came to live in the New Territories. They brought their culture and customs to Hong Kong" (Cheng \& Fung, 2011a, p. 38). Then it states that "Hong Kong's recorded history started during the Qin Dynasty. From that time onwards, Hong Kong has been under Chinese administration" (Cheng \& Fung, 2011a, p. 45). Some other texts in junior history textbooks state that, "[s]ince Hong Kong's recorded history began, it has been ruled by China. Until the mid-19th century, Hong Kong was a traditional Chinese society. The life of Hong Kong people was like the life of people on the mainland" (Cheng \& Fung, 2011b, p. 190), As another junior history textbook states: 
The history of Hong Kong is closely related to that of the mainland. First, we have pottery with geometric patterns similar to that found in central China. Then there are rock carvings that look like those found in Guangdong. About three thousand years ago, many bronze objects were made in Hong Kong. At that time, China was in its Bronze Age. In 221BC, the Qin Emperor unified China and sent troops to occupy the south. In 214 BC, Nanhai County was set up in present-day Guangdong. Hong Kong was part of Panyu Xian, Naihai County. Since then, Hong Kong has become part of China....During the Western Han Dynasty, Hong Kong remained a part of the Panyu Xian, Nanhai County....The shape of the tomb and the objects found inside were similar to those of other Han tombs found in central China. The inscription 'Daji Panyu' on some of the bricks is important evidence that Hong Kong belonged to the Panyu Xian of Nanhai County during the Eastern Han Dynasty. (King \& Leung, 2010a, pp. 46-47)

The period of British colonial rule is glossed over or neglected in these texts. In some junior history textbooks, the historical significance of this period is dismissed, as in the following extract:

Although Hong Kong had been under British administration since 1841, it always maintained a close relationship with the mainland. In fact, Hong Kong's political, social and economic development had always been affected by conditions in the mainland and its policies. (Cheng \& Fung, 2011c, p. 173)

In addition to tracing Hong Kong history back to ancient times, the situation of contemporary Hong Kong is also used in textbooks to strengthen national identity. Many history textbooks repetitively state that:

1) "Hong Kong has always been a Chinese society" (King \& Leung, 2010b, p. 111);

2) "The majority of the population of Hong Kong is Chinese" (Kan, 2007, p. 162);

3) "Hong Kong is a...city where the majority of people is ethnic Chinese" (R. K. L. Cheng, 2014, pp. 1.2-49);

4) "Hong Kong is a territory of China, with close ties and frequent exchanges with the mainland; and Hong Kong residents have been predominantly Chinese, accounting for more than $98 \%$ of the total population, plus they have moved mainly from the mainland; thus Chinese traditional culture, customs and living habits are naturally ingrained in Hong Kong" (R. K. L. Cheng, 2014, pp. 1.2-42);

5) "Hong Kong is a Chinese society deeply influenced by traditional Chinese culture and customs" (R. K. L. Cheng, Fung, Kan, Lau, \& Tang, 2009, p. 105);

6) "Hong Kong's political, social and economic development had always been affected by conditions in the mainland and its policies" (Cheng \& Fung, 2011c, p. 173).

These excerpts clearly construct Chinese identity among Hong Kong people in terms of Mainland Chinese ethnicity and culture. These textbooks also overtly show a Mainland-oriented political position. For example, a text in senior history textbook notes that

In 1970, Hong Kong people began to demand that Chinese become an official language. In 1971, the government set up a committee to study the status of the Chinese language. In 1974, the government amended the Official Languages Ordinance, making Chinese an official language. (R. K. L. Cheng et al., 2009, p. 55) 
As our analysis shows, both Chinese history and history textbooks use local history to foster national pride, especially at the political level. However, the discrepancy between textbooks and the 'reality' in students' minds can intensify a sense of tension among Hong Kong youth in relation to societal concerns regarding nationalism and patriotism. Thus, contrary to the hopes of curriculum writers and textbook publishers, such a focus on national identity in the texts can paradoxically serve to intensify students' sense of a dichotomy between national and local identities, and further fuel the fear of nationalism and blind patriotism.

Related to the theme of nationalism in identity construction in the textbooks, the textbooks also mainly reflect a Mainland-based majority perspective and justify assimilation in history, resulting in a lack of recognition of the many minority groups of Mainland China, of which Hong Kong people may see themselves as part. The traditional perspective used since Ancient China to judge the status of different groups within the Mainland is the distinction of Hua Xia/Yi Di. Hua Xia is a general term to include the groups which were defined as belonging to the Chinese nation. As the predecessor of "Han", the term always connotes the significance of being Chinese, being central, proper, and orthodox. Yi Di describes the groups which were judged as non-Chinese, with connotations historically and today of being marginal and barbarous, and associated with heresy. Although the Hua Xia nation and its culture has been seen as responsible for the stable development of Chinese society, who can be included in the Hua Xia nation is dynamic and flexible. In fact, every group could be included, provided that it acknowledges and accepts the greatness and authority of Hua Xia nation and its culture. Those who do not emphatically acknowledge and accept the greatness and authority of Hua Xia nation and its culture are to be excluded, however, and to be seen as "sinners".

This majority perspective is reflected in junior Chinese history textbooks, which excuse assimilation and territorial expansion in Chinese history with minimizing, euphemistic, passive language, such as "The general trend of the relationship among different ethnic groups is always gradual assimilation" (Liang et al., 2011, p. 6.16). In the five main periods in Chinese history (i.e. from prehistory to the Qing dynasty), a typical majority perspective underlies the narrative regarding the relationship between the Han ethnic group (the dominant group in China) and ethnic minority groups. Nearly all ethnic minorities (e.g., the five $\mathrm{Hu}$ groups, the Xian-Bei, and Mongolians) included in textbooks in these five periods are described as "inferior to the Han" (Du et al., 2012a, p. 166); they "advocated force, and ignored culture and education" (Du et al., 2012b, p. 65); they "frequently resorted to arms and squeezed their subjects, while neglecting agricultural production" (Liang et al., 2011, p. 6.25); and "lacked political foresight, and neglected culture and education" (Tan et al, 1999, p. 45; see also Lin \& Jackson, 2019a).

Behind these narratives is the assumption that Hong Kong people define themselves as Chinese and would associate themselves historically and today with the Hua Xia and Han, respectively. However, according to a survey conducted by HKUPOP, more Hong Kong people tend to define themselves as Hong Kongers than as Chinese, while Hong Kong ethnic minority youth also have no choice to quit the subject(s) or attend other schools with a more inclusive history curriculum.

In relation, the content in textbooks does not provide alternative perspectives, and shows only a dominant value orientation. For instance, in a question asking students to consider "whether it was wise for Emperor Xiao-wen of the Northern Wei dynasty to implement Sini- 
cization" (Du et al., 2012a, p. 166), the assumption that the culture of the Han is more advanced and superior to that of the Xian Bei is taken for granted in both of the two options. The answer to the question that is treated as correct in the textbook is:

The Xian Bei at that time, regardless of population or culture, were inferior to the Han, so it was difficult for them to govern the Han people. The strict Sinicization of Emperor Xiao-wen of Northern Wei dynasty not only improved the culture of the Xian Bei, but also eliminated the contradictions between Han and Hu and thus made regulation easier. Hereby, the Northern Wei dynasty was the longest regime during the Southern and Northern Dynasties period. (Du et al., 2012a, p. 166)

The "incorrect" answer is:

[T]here is no doubt that Sinicization did improve the cultural level of Xian Bei, but it also aroused strong opposition within the Xian Bei, and impaired their loyalty to the royal family. What's worse, the measures (e.g. changing their surnames to Chinese surnames, and intermarrying with Han people) made the Xian Bei blend in with the Han, both from the perspective of consanguinity and culture, and made the Xian Bei disappear from the world. (Du et al., 2012a, p. 166)

In this case, students are precluded from challenging Han cultural superiority, which is in both replies assumed as a matter of fact (Lin \& Jackson, 2019a). In this sense, the textbooks do not provide enough support for students to become active citizens with critical thinking, autonomy, and open-mindedness. Thus the burden of cultivating active citizens with critical thinking, autonomy, and open-mindedness is left to the teachers and the teaching process (e.g. teaching methods), without support from official teaching materials (textbooks).

\section{Conclusion}

History education, if implemented properly, can be valuable for empowering students with knowledge, skills, and values to help enhance societies in the future. However, who has written the history, which history to focus on, and how to interpret it are three fundamental political questions in history education. No answer to these questions can be value-free. It is impossible to focus only on facts in history education, as facts intertwine with politics, such as the consideration of which facts to focus on and include, versus which ones can be neglected. However, even if the involvement of politics in history education is inevitable, one can still deliberate systematically what shape political education should take, and how to conceptualize its ideal and appropriate involvement in history education. Furthermore, history education should recognize its inevitably political nature, to help promote civic goals, such as helping to create an inclusive and a just society.

Based on the analysis of textbooks, we have illustrated how history education in Hong Kong provides a narrow political education, which can impede the crucial education goals in Hong Kong of empowering students to be open-minded, critical thinkers and collaborative problem solvers. As discussed here, controversial issues in history are neglected in curriculum resources, or otherwise brought into Hong Kong schools in a biased and one-sided way via junior history and Chinese history texts. By arguing for more critical orientation to politi- 
cal education in relation to history education, critical political education can help transform the narrowed political lens that has so far been provided, to help Hong Kong achieve its broader civic educational goals.

\section{References}

Adorno, T. W., Frenkel-Brunswik, E., Levinson, D. J., \& Sanford, R. N. (1950). The Authoritarian Personality. New York: Harper.

Barton, K. C., \& Levstik, L. S. (2004). Teaching History for the Common Good. Mahwah, NJ: Lawrence Erlbaum Associates.

Chan, E., \& Chan, J. (2014). Liberal patriotism in Hong Kong. Journal of Contemporary China, 23(89), 952-970.

Cheng, K. L., \& Fung, S. K. (2011a). Traveling through History (1A). Hong Kong: Aristo Educational Press.

Cheng, K. L., \& Fung, S. K. (2011b). Traveling through History (2B). Hong Kong: Aristo Educational Press.

Cheng, K. L., \& Fung, S. K. (2011c). Traveling through History (3B). Hong Kong: Aristo Educational Press.

Cheng, R. K. L. (2014). HKDSE World History: A New Approach (Introduction \& Theme A). Hong Kong: Aristo Educational Press Ltd.

Cheng, R. K. L., Fung, V. S. K., Kan, N. Y. Y., Lau, A. M. S., \& Tang, M. K. L. (2009). HKDSE History Inquiry Vol. I. Hong Kong: Aristo Educational Press Ltd.

Chiu, P., \& Yeung. R. (2017). Roundabout route to national education? Chinese history rule for Hong Kong secondary schools stokes fears of renewed push. South China Morning Post, 12 October.

Curriculum Development Council and The Hong Kong Examinations and Assessment Authority (2015). History Curriculum and Assessment Guide (Secondary 4-6). Hong Kong: Education Bureau.

Curriculum Development Council Committee on Personal, Social and Humanities Education (2016). History (Secondary 1-3) The Revised Curriculum First Draft (For Consultation). Hong Kong: Education Bureau.

Down, B. (2004). From patriotism to critical democracy: shifting discourses of citizenship education in social studies. History of Education Review, 33(1), 14-27.

Du, Z. Z., Hu, Z. W., Liang, G. X., Qu, D. R., Guang, W. H., Rong, Z. S., Chen, Z. W., Zhen, J. T., (2012a). New Concepts in Chinese History (third edition) (1). Hong Kong Educational Publishing Company.

Du, Z. Z., Hu, Z. W., Liang, G. X., Qu, D. R., Guang, W. H., Rong, Z. S., Chen, Z. W., Zhen, J. T., (2012b). New Concepts in Chinese History (third edition) (2). Hong Kong Educational Publishing Company.

Fairbrother, G. P. (2003). Toward Critical Patriotism: Student Resistance to Political Education in Hong Kong and China. Hong Kong: Hong Kong University Press.

Fraenkel, J., Wallen, N., \& Hyun, H. (2015). How to Design and Evaluate Research in Education. New York: McGraw-Hill.

Foucault, M. (1977). Discipline and Punish: The Birth of the Prison. New York: Vintage Books.

Green, B. (1986). Reading reproduction theory: on the ideology and education debate. Discourse: Studies in the Cultural Politics of Education, 6(2), 1-31.

Jackson, L. (2014a). Muslims and Islam in U.S. Education: Reconsidering Multiculturalism. London; New York: Routledge.

Jackson, L. (2014b). Under construction: the development of multicultural curriculum in Hong Kong and Taiwan. The Asia-Pacific Education Researcher, 23(4), 885-893.

Kan, F. (2007). Hong Kong's Chinese History Curriculum from 1945. Hong Kong: Hong Kong University Press.

Kan, F, \& Vickers, E. (2002). One Hong Kong, two histories: "History" and "Chinese History" in the Hong Kong school curriculum. Comparative Education, 38(1), 73-89. 
Kan, N. Y. Y. (2007). New Journey through History 2B. Hong Kong: Aristo Educational Press Ltd.

King, G., \& Leung, K. T. (2010a). World History Express (second edition) 1A. Hong Kong: Ling Kee Publishing Co Ltd.

King, G., \& Leung, K. T. (2010b). World History Express (second edition) 2B. Hong Kong: Ling Kee Publishing Co Ltd.

Korostelina, K. (2008). History education and social identity. Identity, 8(1), 25-45.

Kwok, H. (2017). Can Hong Kong's revived Chinese history curriculum serve to cement a national identity?. Hong Kong Free Press, 15 October.

Liang, Y. M., Liang, C. Y., Ye, X. B., Deng, J. L., Lin, B. Y. (2011). Comprehensive Chinese History (1). Hong Kong: Marshall Cavendish Education.

Li, W. X., Xu, X. Q., and P. Fu. (2012). Traveling through Chinese History (1A). Hong Kong: Aristo Educational Press.

Lin, C., \& Jackson, L. (2019a). Multiculturalism in Chinese History in Hong Kong: Constructing Chinese identity. Asia Pacific Journal of Education, forthcoming.

Lin, C., \& Jackson, L. (2019b). From Shared Fate to Shared Fates: Citizenship and Multiculturalism in Education, forthcoming.

McGuire, J. (2017). How Hong Kong history teachers could make secondary school lessons less boring. South China Morning Post, 04 May.

Pang, B. (2017). National education will teach HK children a sense of 'I am Chinese', says Carrie Lam. Youngpost, 22 June.

Schatz, R., Staub, E. \& Lavine, H. (1999). On the varieties of national attachment: Blind versus constructive patriotism. Political Psychology, 20, 151-174.

Schmitz, R. (2017). Worries grow In Hong Kong as China pushes its official version of history in schools. Parallels, 11 December.

SCMP Editorial. (2017). Identity and history are part of education. South China Morning Post, 16 October.

Sen, A. (2006). Identity and Violence: The Illusion of Destiny. London: Penguin Books.

Staub, E. (1997). Blind versus constructive patriotism: Moving from embeddedness in the group to critical loyalty and action. In D. Bar-Tal \& E. Staub (Eds), Patriotism in the Lives of Individuals and Nations (pp. 213-228). Chicago: Nelson-Hall.

Tan, S. S., Luo, G. R., Huang, J. L., Chen, Z. H. (2009). Chinese History (third edition) (3B). Hong Kong: Modern Educational Research Society.

Tan, S. S., Chen, Z. H., Huang, J. L., Luo, G. R. (1999). Chinese History (2). Hong Kong: Modern Educational Research Society.

Vickers, E. (2005). In Search of an Identity: The Politics of History as a School Subject in Hong Kong, 1960s-2005. Hong Kong: Comparative Education Research Centre/The University of Hong Kong.

Yogev, E. (2013). On the need to strengthen political-critical thinking in history education. International Review of Education, 59(5), 627-645.

Yuen, T., \& Byram, M. (2007). National identity, patriotism and studying politics in schools: a case study in Hong Kong. Compare: A Journal of Comparative and International Education,37(1), 2336 .

\section{Appendix}

List of Chinese history textbooks used in the study.

\begin{tabular}{|c|c|c|c|c|c|c|c|}
\hline No. & Publisher & Title & Volume & Authors & Year & $\begin{array}{c}\text { Curriculum } \\
\text { Document }\end{array}$ & $\begin{array}{c}\text { Grade of } \\
\text { Targeted } \\
\text { Students }\end{array}$ \\
\hline 1 & $\begin{array}{c}\text { Hong Kong } \\
\text { Educational } \\
\text { Publishing } \\
\text { Company }\end{array}$ & $\begin{array}{c}\text { 新理念中國歷史 (第三版) } \\
\text { (New Concepts in Chinese } \\
\text { History (Third Edition)) }\end{array}$ & $\begin{array}{c}\text { 第一冊 } \\
\text { (Volume 1) }\end{array}$ & $\begin{array}{l}\text { 杜振醉、胡志偉、 } \\
\text { 㨽文慧、容子思、 } \\
\text { 陳志偉、甄錦棠 }\end{array}$ & 2012 & Syllabus \\
1997 & Grade 7 \\
\hline
\end{tabular}




\begin{tabular}{|c|c|c|c|c|c|c|c|}
\hline 2 & $\begin{array}{c}\text { Hong Kong } \\
\text { Educational } \\
\text { Publishing } \\
\text { Company }\end{array}$ & $\begin{array}{c}\text { 新理念中國歷史（第三版） } \\
\text { (New Concepts in Chinese } \\
\text { History (Third Edition)) }\end{array}$ & $\begin{array}{c}\text { 第二冊 } \\
\text { (Volume 2) }\end{array}$ & $\begin{array}{l}\text { 杜振醉、胡志偉、 } \\
\text { 梁國雄、區達仁、 } \\
\text { 鋮文慧、容子思、 } \\
\text { 陳志偉、甄錦棠 }\end{array}$ & 2012 & $\begin{array}{c}\text { Syllabus } \\
1997\end{array}$ & Grade 8 \\
\hline 3 & $\begin{array}{l}\text { Hong Kong } \\
\text { Educational } \\
\text { Publishing } \\
\text { Company }\end{array}$ & $\begin{array}{c}\text { 新理念中國歷史（第三版） } \\
\text { (New Concepts in Chinese } \\
\text { History (Third Edition)) }\end{array}$ & $\begin{array}{c}\text { 第三冊 } \\
\text { (Volume 3) }\end{array}$ & $\begin{array}{l}\text { 杜振醉、胡志偉、 } \\
\text { 梁國雄、區達仁、 } \\
\text { 廣文慧、容子思、 } \\
\text { 陳志偉、甄錦棠 }\end{array}$ & 2012 & $\begin{array}{c}\text { Syllabus } \\
1997\end{array}$ & Grade 9 \\
\hline 4 & $\begin{array}{c}\text { Marshall } \\
\text { Cavendish } \\
\text { Education }\end{array}$ & $\begin{array}{c}\text { 全方位中國歷史 (Comprehen- } \\
\text { sive Chinese History) }\end{array}$ & 1 & $\begin{array}{l}\text { 梁一鳴、梁操雅、 } \\
\text { 葉小兵、鄧京力、 } \\
\text { 林寶英 }\end{array}$ & 2011 & $\begin{array}{c}\text { Syllabus } \\
1997\end{array}$ & Grade 7 \\
\hline 5 & $\begin{array}{l}\text { Marshall } \\
\text { Cavendish } \\
\text { Education }\end{array}$ & $\begin{array}{c}\text { 全方位中國歷史 (Comprehen- } \\
\text { sive Chinese History) }\end{array}$ & 2 & $\begin{array}{l}\text { 梁一鳴、梁操雅、 } \\
\text { 葉小兵、鄧京力、 } \\
\text { 林寶英 }\end{array}$ & 2011 & $\begin{array}{c}\text { Syllabus } \\
1997\end{array}$ & Grade 8 \\
\hline 6 & $\begin{array}{l}\text { Marshall } \\
\text { Cavendish } \\
\text { Education }\end{array}$ & $\begin{array}{c}\text { 全方位中國歷史 (Comprehen- } \\
\text { sive Chinese History) }\end{array}$ & 3 上 $(3 \mathrm{~A})$ & $\begin{array}{l}\text { 梁一鳴、梁操雅、 } \\
\text { 葉小兵、鄧京力、 } \\
\text { 林寶英 }\end{array}$ & 2011 & $\begin{array}{c}\text { Syllabus } \\
1997\end{array}$ & Grade 9 \\
\hline 7 & $\begin{array}{l}\text { Marshall } \\
\text { Cavendish } \\
\text { Education }\end{array}$ & $\begin{array}{c}\text { 全方位中國歷史 (Comprehen- } \\
\text { sive Chinese History) }\end{array}$ & 3 下 (3B) & $\begin{array}{l}\text { 梁一鳴、梁操雅、 } \\
\text { 葉小兵、鄧京力、 } \\
\text { 林寶英 }\end{array}$ & 2011 & $\begin{array}{c}\text { Syllabus } \\
1997\end{array}$ & Grade 9 \\
\hline 8 & $\begin{array}{l}\text { Modern } \\
\text { Educational } \\
\text { Research } \\
\text { Society, Ltd }\end{array}$ & 中國歷史 (Chinese History) & 1 & $\begin{array}{l}\text { 譚松壽、陳志華、 } \\
\text { 黃家樑、羅國潤 }\end{array}$ & 1999 & $\begin{array}{c}\text { Syllabus } \\
1997\end{array}$ & Grade 7 \\
\hline 9 & $\begin{array}{l}\text { Modern } \\
\text { Educational } \\
\text { Research } \\
\text { Society, Ltd }\end{array}$ & 中國歷史 (Chinese History) & 2 & $\begin{array}{l}\text { 譚松壽、陳志華、 } \\
\text { 黃家樑、羅國潤 }\end{array}$ & 1999 & $\begin{array}{c}\text { Syllabus } \\
1997\end{array}$ & Grade 8 \\
\hline 10 & $\begin{array}{l}\text { Modern } \\
\text { Educational } \\
\text { Research } \\
\text { Society, Ltd }\end{array}$ & 中國歷史 (Chinese History) & 3 & $\begin{array}{l}\text { 譚松壽、陳志華、 } \\
\text { 黃家樑、羅國潤 }\end{array}$ & 1999 & $\begin{array}{c}\text { Syllabus } \\
1997\end{array}$ & Grade 9 \\
\hline 11 & $\begin{array}{l}\text { Modern } \\
\text { Educational } \\
\text { Research } \\
\text { Society, Ltd } \\
\end{array}$ & $\begin{array}{c}\text { 中國歷史 (第三版) (Chinese } \\
\text { History) }\end{array}$ & 1 & $\begin{array}{l}\text { 譚松壽、羅國潤、 } \\
\text { 黃家樑、陳志華 }\end{array}$ & 2009 & $\begin{array}{c}\text { Syllabus } \\
1997\end{array}$ & Grade 7 \\
\hline 12 & $\begin{array}{l}\text { Modern } \\
\text { Educational } \\
\text { Research } \\
\text { Society, Ltd }\end{array}$ & $\begin{array}{c}\text { 中國歷史 (第三版) (Chinese } \\
\text { History) }\end{array}$ & 2 & $\begin{array}{l}\text { 譚松壽、羅國潤、 } \\
\text { 黃家樑、陳志華 }\end{array}$ & 2009 & $\begin{array}{c}\text { Syllabus } \\
1997\end{array}$ & Grade 8 \\
\hline 13 & $\begin{array}{l}\text { Modern } \\
\text { Educational } \\
\text { Research } \\
\text { Society, Ltd }\end{array}$ & $\begin{array}{c}\text { 中國歷史 (第三版) (Chinese } \\
\text { History) }\end{array}$ & 3 上 $(3 \mathrm{~A})$ & $\begin{array}{l}\text { 譚松壽、羅國潤、 } \\
\text { 黃家樑、陳志華 }\end{array}$ & 2009 & $\begin{array}{c}\text { Syllabus } \\
1997\end{array}$ & Grade 9 \\
\hline 14 & $\begin{array}{c}\text { Modern } \\
\text { Educational } \\
\text { Research } \\
\text { Society, Ltd }\end{array}$ & $\begin{array}{c}\text { 中國歷史 (第三版) (Chinese } \\
\text { History) }\end{array}$ & 3 下 (3B) & $\begin{array}{l}\text { 譚松壽、羅國潤、 } \\
\text { 黃家樑、陳志華 }\end{array}$ & 2009 & $\begin{array}{c}\text { Syllabus } \\
1997\end{array}$ & Grade 9 \\
\hline 15 & $\begin{array}{c}\text { Aristo } \\
\text { Educational } \\
\text { Press Ltd }\end{array}$ & $\begin{array}{l}\text { 中國史遊蹤 (Traveling } \\
\text { Through Chinese History) }\end{array}$ & 1 甲 (1A) & $\begin{array}{l}\text { 李偉雄、徐曉琦、 } \\
\text { 傅萍 }\end{array}$ & 2012 & $\begin{array}{c}\text { Syllabus } \\
1997\end{array}$ & Grade 7 \\
\hline 16 & $\begin{array}{c}\text { Aristo } \\
\text { Educational } \\
\text { Press Ltd }\end{array}$ & $\begin{array}{l}\text { 中國史遊蹤 (Traveling } \\
\text { Through Chinese History) }\end{array}$ & 1 乙 (1B) & $\begin{array}{l}\text { 李偉雄、徐曉琦、 } \\
\text { 傅萍 }\end{array}$ & 2012 & $\begin{array}{c}\text { Syllabus } \\
1997\end{array}$ & Grade 7 \\
\hline 17 & $\begin{array}{c}\text { Aristo } \\
\text { Educational } \\
\text { Press Ltd }\end{array}$ & $\begin{array}{l}\text { 中國史遊蹤 (Traveling } \\
\text { Through Chinese History) }\end{array}$ & 2 甲 $(2 \mathrm{~A})$ & $\begin{array}{l}\text { 李偉雄、徐曉琦、 } \\
\text { 傅萍 }\end{array}$ & 2012 & $\begin{array}{c}\text { Syllabus } \\
1997\end{array}$ & Grade 8 \\
\hline
\end{tabular}




\begin{tabular}{|c|c|c|c|c|c|c|c|}
\hline 18 & $\begin{array}{l}\text { Aristo } \\
\text { Educational } \\
\text { Press Ltd }\end{array}$ & $\begin{array}{l}\text { 中國史遊蹤 (Traveling } \\
\text { Through Chinese History) }\end{array}$ & 2 乙 $(2 B)$ & $\begin{array}{l}\text { 李偉雄、徐曉琦、 } \\
\text { 傅萍 }\end{array}$ & 2012 & $\begin{array}{c}\text { Syllabus } \\
1997\end{array}$ & Grade 8 \\
\hline 19 & $\begin{array}{c}\text { Aristo } \\
\text { Educational } \\
\text { Press Ltd }\end{array}$ & $\begin{array}{l}\text { 中國史遊蹤 (Traveling } \\
\text { Through Chinese History) }\end{array}$ & 3 甲上 & $\begin{array}{l}\text { 李偉雄、徐曉琦、 } \\
\text { 傅萍 }\end{array}$ & 2012 & $\begin{array}{l}\text { Syllabus } \\
1997\end{array}$ & Grade 9 \\
\hline 20 & $\begin{array}{l}\text { Aristo } \\
\text { Educational } \\
\text { Press Ltd }\end{array}$ & $\begin{array}{l}\text { 中國史遊蹤 (Travelling } \\
\text { Through Chinese History) }\end{array}$ & 3 甲下 & $\begin{array}{l}\text { 李偉雄、徐曉琦、 } \\
\text { 傅萍 }\end{array}$ & 2012 & $\begin{array}{c}\text { Syllabus } \\
1997\end{array}$ & Grade 9 \\
\hline 21 & $\begin{array}{l}\text { Aristo } \\
\text { Educational } \\
\text { Press Ltd }\end{array}$ & $\begin{array}{c}\text { 中國史遊蹤 (Traveling } \\
\text { Through Chinese History) }\end{array}$ & $3 乙$ & $\begin{array}{l}\text { 李偉雄、徐曉琦、 } \\
\text { 傅萍 }\end{array}$ & 2012 & $\begin{array}{l}\text { Syllabus } \\
1997\end{array}$ & Grade 9 \\
\hline 22 & \begin{tabular}{|c|} 
Ling Kee \\
Publishing Co \\
Ltd
\end{tabular} & $\begin{array}{c}\text { 新簡明中國史 (第二版) (New } \\
\text { Concise Chinese History } \\
\text { (Second Edition)) }\end{array}$ & $\begin{array}{c}1 \text { (甲部課程) } \\
\text { (Part A } \\
\text { Topics) }\end{array}$ & $\begin{array}{l}\text { 陳漢森、洪天宇、 } \\
\text { 羅國持 }\end{array}$ & 2013 & $\begin{array}{c}\text { Syllabus } \\
1997\end{array}$ & Grade 7 \\
\hline 23 & \begin{tabular}{|c|} 
Ling Kee \\
Publishing Co \\
Ltd
\end{tabular} & $\begin{array}{c}\text { 新簡明中國史 (第二版) (New } \\
\text { Concise Chinese History } \\
\text { (Second Edition)) }\end{array}$ & $\begin{array}{c}1 \text { (乙部課程 }) \\
\text { (Part B Topics) }\end{array}$ & $\begin{array}{l}\text { 陳漢森、洪天宇、 } \\
\text { 羅國持 }\end{array}$ & 2013 & $\begin{array}{c}\text { Syllabus } \\
1997\end{array}$ & Grade 7 \\
\hline 24 & \begin{tabular}{|c|} 
Ling Kee \\
Publishing Co \\
Ltd
\end{tabular} & $\begin{array}{c}\text { 新簡明中國史 (第二版) (New } \\
\text { Concise Chinese History } \\
\text { (Second Edition)) }\end{array}$ & $\begin{array}{c}2 \text { (甲部課程) } \\
\text { (Part A } \\
\text { Topics) }\end{array}$ & $\begin{array}{l}\text { 陳漢森、洪天宇、 } \\
\text { 羅國持 }\end{array}$ & 2013 & $\begin{array}{c}\text { Syllabus } \\
1997\end{array}$ & Grade 8 \\
\hline 25 & \begin{tabular}{|c} 
Ling Kee \\
Publishing Co \\
Ltd
\end{tabular} & $\begin{array}{c}\text { 新簡明中國史 (第二版) (New } \\
\text { Concise Chinese History } \\
\text { (Second Edition)) }\end{array}$ & $\begin{array}{c}2 \text { (乙部課程 }) \\
\text { (Part B Topics) }\end{array}$ & $\begin{array}{l}\text { 陳漢森、洪天宇、 } \\
\text { 羅國持 }\end{array}$ & 2013 & $\begin{array}{c}\text { Syllabus } \\
1997\end{array}$ & Grade 8 \\
\hline 26 & \begin{tabular}{|c} 
Ling Kee \\
Publishing Co \\
Ltd
\end{tabular} & $\begin{array}{c}\text { 新簡明中國史 (第二版) (New } \\
\text { Concise Chinese History } \\
\text { (Second Edition)) }\end{array}$ & $\begin{array}{c}3 \text { (甲部課程) } \\
\text { (Part A } \\
\text { Topics) }\end{array}$ & $\begin{array}{l}\text { 陳漢森、洪天宇、 } \\
\text { 羅國持 }\end{array}$ & 2013 & $\begin{array}{c}\text { Syllabus } \\
1997\end{array}$ & Grade 9 \\
\hline 27 & \begin{tabular}{|c} 
Ling Kee \\
Publishing Co \\
Ltd
\end{tabular} & $\begin{array}{c}\text { 新簡明中國史 (第二版) (New } \\
\text { Concise Chinese History } \\
\text { (Second Edition)) }\end{array}$ & $\begin{array}{c}3 \text { (乙部課程 }) \\
\text { (Part B Topics) }\end{array}$ & $\begin{array}{l}\text { 陳漢森、洪天宇、 } \\
\text { 羅國持 }\end{array}$ & 2013 & $\begin{array}{c}\text { Syllabus } \\
1997\end{array}$ & Grade 9 \\
\hline 28 & $\begin{array}{l}\text { Sky Education } \\
\text { Press (HK) } \\
\text { Ltd. }\end{array}$ & $\begin{array}{c}\text { 初中中國歷史 (Junior } \\
\text { Secondary Chinese History) }\end{array}$ & $1 \mathrm{~A}$ & 梁國全、沈思敏 & 2012 & $\begin{array}{c}\text { Syllabus } \\
1997\end{array}$ & Grade 7 \\
\hline 29 & $\begin{array}{l}\text { Sky Education } \\
\text { Press (HK) } \\
\text { Ltd. } \\
\end{array}$ & $\begin{array}{c}\text { 初中中國歷史 (Junior } \\
\text { Secondary Chinese History) }\end{array}$ & 1B & 梁國全、沈思敏 & 2012 & $\begin{array}{c}\text { Syllabus } \\
1997\end{array}$ & Grade 7 \\
\hline 30 & $\begin{array}{l}\text { Sky Education } \\
\text { Press (HK) } \\
\text { Ltd. }\end{array}$ & $\begin{array}{c}\text { 初中中國歷史 (Junior } \\
\text { Secondary Chinese History) }\end{array}$ & $1 \mathrm{C}$ & 梁國全、沈思敏 & 2012 & $\begin{array}{c}\text { Syllabus } \\
1997\end{array}$ & Grade 7 \\
\hline 31 & $\begin{array}{l}\text { Sky Education } \\
\text { Press (HK) } \\
\text { Ltd. } \\
\end{array}$ & $\begin{array}{c}\text { 初中中國歷史 (Junior } \\
\text { Secondary Chinese History) }\end{array}$ & $2 \mathrm{~A}$ & 梁國全、沈思敏 & 2012 & $\begin{array}{c}\text { Syllabus } \\
1997\end{array}$ & Grade 8 \\
\hline 32 & $\begin{array}{l}\text { Sky Education } \\
\text { Press (HK) } \\
\text { Ltd. }\end{array}$ & $\begin{array}{c}\text { 初中中國歷史 (Junior } \\
\text { Secondary Chinese History) }\end{array}$ & $2 \mathrm{~B}$ & 梁國全、沈思敏 & 2012 & $\begin{array}{c}\text { Syllabus } \\
1997\end{array}$ & Grade 8 \\
\hline 33 & \begin{tabular}{|c|} 
Ling Kee \\
Publishing Co \\
Ltd \\
\end{tabular} & $\begin{array}{c}\text { 新簡明中國史 (第二版) (New } \\
\text { Concise Chinese History } \\
\text { (Second Edition)) }\end{array}$ & $\begin{array}{c}1 \text { (甲部課程) } \\
\text { (Part A } \\
\text { Topics) }\end{array}$ & $\begin{array}{l}\text { 陳漢森、洪天宇、 } \\
\text { 羅國持 }\end{array}$ & 2013 & $\begin{array}{c}\text { Syllabus } \\
1997\end{array}$ & Grade 7 \\
\hline 34 & \begin{tabular}{|c} 
Ling Kee \\
Publishing Co \\
Ltd
\end{tabular} & $\begin{array}{c}\text { 新簡明中國史 (第二版) (New } \\
\text { Concise Chinese History } \\
\text { (Second Edition)) }\end{array}$ & $\begin{array}{c}2 \text { (甲部課程) } \\
\text { (Part A } \\
\text { Topics) }\end{array}$ & $\begin{array}{l}\text { 陳漢森、洪天宇、 } \\
\text { 羅國持 }\end{array}$ & 2013 & $\begin{array}{c}\text { Syllabus } \\
1997\end{array}$ & Grade 8 \\
\hline 35 & \begin{tabular}{|c|} 
Ling Kee \\
Publishing Co \\
Ltd
\end{tabular} & $\begin{array}{c}\text { 新簡明中國史 (第二版) (New } \\
\text { Concise Chinese History } \\
\text { (Second Edition)) }\end{array}$ & $\begin{array}{c}3 \text { (甲部課程) } \\
\text { (Part A } \\
\text { Topics) }\end{array}$ & $\begin{array}{l}\text { 陳漢森、洪天宇、 } \\
\text { 羅國持 }\end{array}$ & 2013 & $\begin{array}{c}\text { Syllabus } \\
1997\end{array}$ & Grade 9 \\
\hline
\end{tabular}


List of history textbooks used in the study.

\begin{tabular}{|c|c|c|c|c|c|c|c|}
\hline No. & Publisher & Title & Volume & Authors & Year & $\begin{array}{l}\text { Curriculum } \\
\text { Document }\end{array}$ & $\begin{array}{l}\text { Grade of } \\
\text { Targeted } \\
\text { Students }\end{array}$ \\
\hline 1 & $\begin{array}{c}\text { Aristo Educa- } \\
\text { tional Press Ltd }\end{array}$ & $\begin{array}{c}\text { Travelling Through } \\
\text { History }\end{array}$ & $1 \mathrm{~A}$ & $\begin{array}{l}\text { Rita K.L. Cheng, } \\
\text { Venus S.K. Fung }\end{array}$ & 2011 & Syllabus 1996 & Grade 7 \\
\hline 2 & $\begin{array}{l}\text { Aristo Educa- } \\
\text { tional Press Ltd }\end{array}$ & $\begin{array}{c}\text { Travelling Through } \\
\text { History }\end{array}$ & 1B & $\begin{array}{l}\text { Rita K.L. Cheng, } \\
\text { Venus S.K. Fung }\end{array}$ & 2011 & Syllabus 1996 & Grade 7 \\
\hline 3 & $\begin{array}{l}\text { Aristo Educa- } \\
\text { tional Press Ltd }\end{array}$ & $\begin{array}{c}\text { Travelling Through } \\
\text { History }\end{array}$ & $2 \mathrm{~A}$ & $\begin{array}{l}\text { Rita K.L. Cheng, } \\
\text { Venus S.K. Fung }\end{array}$ & 2011 & Syllabus 1996 & Grade 8 \\
\hline 4 & $\begin{array}{l}\text { Aristo Educa- } \\
\text { tional Press Ltd }\end{array}$ & $\begin{array}{c}\text { Travelling Through } \\
\text { History }\end{array}$ & $2 \mathrm{~B}$ & $\begin{array}{l}\text { Rita K.L. Cheng, } \\
\text { Venus S.K. Fung }\end{array}$ & 2011 & Syllabus 1996 & Grade 8 \\
\hline 5 & $\begin{array}{l}\text { Aristo Educa- } \\
\text { tional Press Ltd }\end{array}$ & \begin{tabular}{|c} 
Travelling Through \\
History
\end{tabular} & $3 \mathrm{~A}$ & $\begin{array}{l}\text { Rita K.L. Cheng, } \\
\text { Venus S.K. Fung }\end{array}$ & 2011 & Syllabus 1996 & Grade 9 \\
\hline 6 & $\begin{array}{l}\text { Aristo Educa- } \\
\text { tional Press Ltd }\end{array}$ & \begin{tabular}{|c} 
Travelling Through \\
History
\end{tabular} & $3 \mathrm{~B}$ & $\begin{array}{l}\text { Rita K.L. Cheng, } \\
\text { Venus S.K. Fung }\end{array}$ & 2011 & Syllabus 1996 & Grade 9 \\
\hline 7 & $\begin{array}{l}\text { Aristo Educa- } \\
\text { tional Press Ltd }\end{array}$ & $\begin{array}{l}\text { New Journey } \\
\text { Through History } \\
\text { (Second Edition) }\end{array}$ & $1 \mathrm{~A}$ & $\begin{array}{c}\text { Rita K. L. CHENG, } \\
\text { HUI Ka Yin }\end{array}$ & 2016 & Syllabus 1996 & Grade 7 \\
\hline 8 & $\begin{array}{l}\text { Aristo Educa- } \\
\text { tional Press Ltd }\end{array}$ & $\begin{array}{l}\text { New Journey } \\
\text { Through History } \\
\text { (Second Edition) }\end{array}$ & $1 \mathrm{~B}$ & $\begin{array}{c}\text { Rita K. L. CHENG, } \\
\text { HUI Ka Yin }\end{array}$ & 2016 & Syllabus 1996 & Grade 7 \\
\hline 9 & $\begin{array}{l}\text { Aristo Educa- } \\
\text { tional Press Ltd }\end{array}$ & $\begin{array}{l}\text { New Journey } \\
\text { Through History } \\
\text { (Second Edition) }\end{array}$ & $2 \mathrm{~A}$ & $\begin{array}{c}\text { Rita K. L. CHENG, } \\
\text { HUI Ka Yin }\end{array}$ & $\begin{array}{l}2016 \\
(\mathrm{CHI}) / \\
2017 \\
(\mathrm{ENG})\end{array}$ & Syllabus 1996 & Grade 8 \\
\hline 10 & $\begin{array}{l}\text { Aristo Educa- } \\
\text { tional Press Ltd }\end{array}$ & $\begin{array}{l}\text { New Journey } \\
\text { Through History } \\
\text { (Second Edition) }\end{array}$ & $2 \mathrm{~B}$ & $\begin{array}{c}\text { Rita K. L. CHENG, } \\
\text { HUI Ka Yin }\end{array}$ & $\begin{array}{l}2016 \\
(\mathrm{CHI}) / \\
2017 \\
(\mathrm{ENG})\end{array}$ & Syllabus 1996 & Grade 8 \\
\hline 11 & $\begin{array}{l}\text { Aristo Educa- } \\
\text { tional Press Ltd }\end{array}$ & $\begin{array}{l}\text { New Journey } \\
\text { Through History } \\
\text { (Second Edition) }\end{array}$ & $3 \mathrm{~A}$ & $\begin{array}{c}\text { Rita K. L. CHENG, } \\
\text { HUI Ka Yin }\end{array}$ & 2015 & Syllabus 1996 & Grade 9 \\
\hline 12 & $\begin{array}{l}\text { Aristo Educa- } \\
\text { tional Press Ltd }\end{array}$ & $\begin{array}{l}\text { New Journey } \\
\text { Through History } \\
\text { (Second Edition) }\end{array}$ & $3 \mathrm{~B}$ & $\begin{array}{c}\text { Rita K. L. CHENG, } \\
\text { HUI Ka Yin }\end{array}$ & 2015 & Syllabus 1996 & Grade 9 \\
\hline 13 & $\begin{array}{c}\text { Ling Kee } \\
\text { Publishing Co } \\
\text { Ltd }\end{array}$ & $\begin{array}{l}\text { World History } \\
\text { Express (Second } \\
\text { Edition) }\end{array}$ & $1 \mathrm{~A}$ & $\begin{array}{l}\text { Gordon King, Kwok } \\
\text { Tat Leung }\end{array}$ & 2010 & Syllabus 1996 & Grade 7 \\
\hline 14 & $\begin{array}{c}\text { Ling Kee } \\
\text { Publishing Co } \\
\text { Ltd }\end{array}$ & $\begin{array}{l}\text { World History } \\
\text { Express (Second } \\
\text { Edition) }\end{array}$ & 1B & $\begin{array}{l}\text { Gordon King, Kwok } \\
\text { Tat Leung }\end{array}$ & 2010 & Syllabus 1996 & Grade 7 \\
\hline 15 & $\begin{array}{c}\text { Ling Kee } \\
\text { Publishing Co } \\
\text { Ltd }\end{array}$ & $\begin{array}{l}\text { World History } \\
\text { Express (Second } \\
\text { Edition) }\end{array}$ & $2 \mathrm{~A}$ & $\begin{array}{l}\text { Gordon King, Kwok } \\
\text { Tat Leung }\end{array}$ & 2010 & Syllabus 1996 & Grade 8 \\
\hline 16 & $\begin{array}{c}\text { Ling Kee } \\
\text { Publishing Co } \\
\text { Ltd }\end{array}$ & $\begin{array}{l}\text { World History } \\
\text { Express (Second } \\
\text { Edition) }\end{array}$ & $2 \mathrm{~B}$ & $\begin{array}{l}\text { Gordon King, Kwok } \\
\text { Tat Leung }\end{array}$ & 2010 & Syllabus 1996 & Grade 8 \\
\hline 17 & $\begin{array}{c}\text { Ling Kee } \\
\text { Publishing Co } \\
\text { Ltd }\end{array}$ & $\begin{array}{l}\text { World History } \\
\text { Express (Second } \\
\text { Edition) }\end{array}$ & 3B & $\begin{array}{l}\text { Gordon King, Kwok } \\
\text { Tat Leung }\end{array}$ & 2010 & Syllabus 1996 & Grade 9 \\
\hline 18 & $\begin{array}{c}\text { Ling Kee } \\
\text { Publishing Co } \\
\text { Ltd }\end{array}$ & $\begin{array}{l}\text { Exploring World } \\
\text { History }\end{array}$ & $1 \mathrm{~A}$ & $\begin{array}{c}\text { Gordon King, Frank } \\
\text { Owen }\end{array}$ & 1998 & Syllabus 1996 & Grade 7 \\
\hline
\end{tabular}




\begin{tabular}{|c|c|c|c|c|c|c|c|}
\hline 19 & $\begin{array}{c}\text { Ling Kee } \\
\text { Publishing Co } \\
\text { Ltd }\end{array}$ & $\begin{array}{l}\text { Exploring World } \\
\text { History }\end{array}$ & $2 \mathrm{~B}$ & $\begin{array}{c}\text { Gordon King, Frank } \\
\text { Owen }\end{array}$ & 1999 & Syllabus 1996 & Grade 8 \\
\hline 20 & $\begin{array}{c}\text { Ling Kee } \\
\text { Publishing Co } \\
\text { Ltd }\end{array}$ & $\begin{array}{l}\text { Exploring World } \\
\text { History }\end{array}$ & 3 & $\begin{array}{l}\text { Gordon King, Frank } \\
\text { Owen }\end{array}$ & 2000 & Syllabus 1996 & Grade 9 \\
\hline 21 & $\begin{array}{c}\text { Ling Kee } \\
\text { Publishing Co } \\
\text { Ltd }\end{array}$ & $\begin{array}{l}\text { New Exploring } \\
\text { World History }\end{array}$ & 3 & $\begin{array}{l}\text { LAU Wai-wah, SU } \\
\text { Sian-long, Charlotte } \\
\text { CHOI }\end{array}$ & 2006 & Syllabus 1996 & Grade 9 \\
\hline 22 & $\begin{array}{l}\text { Aristo Educa- } \\
\text { tional Press Ltd }\end{array}$ & $\begin{array}{l}\text { New Journey } \\
\text { Through History }\end{array}$ & $1 \mathrm{~A}$ & Nelson Y. Y. Kan & 2007 & Syllabus 1996 & Grade 7 \\
\hline 23 & $\begin{array}{l}\text { Aristo Educa- } \\
\text { tional Press Ltd }\end{array}$ & $\begin{array}{l}\text { New Journey } \\
\text { Through History }\end{array}$ & $2 \mathrm{~B}$ & Nelson Y. Y. Kan & 2007 & Syllabus 1996 & Grade 8 \\
\hline 24 & $\begin{array}{l}\text { Aristo Educa- } \\
\text { tional Press Ltd }\end{array}$ & $\begin{array}{l}\text { New Journey } \\
\text { Through History }\end{array}$ & 3B & Nelson Y. Y. Kan & 2007 & Syllabus 1996 & Grade 9 \\
\hline 25 & $\begin{array}{l}\text { Hong Kong } \\
\text { Educational } \\
\text { Publishing } \\
\text { Company }\end{array}$ & $\begin{array}{l}\text { New Horizon Histo- } \\
\text { ry }\end{array}$ & Introduction & W.F. Wong & 2009 & $\begin{array}{l}\text { C\&A Guide } \\
2007\end{array}$ & Grade 10 \\
\hline 26 & $\begin{array}{l}\text { Hong Kong } \\
\text { Educational } \\
\text { Publishing } \\
\text { Company }\end{array}$ & $\begin{array}{l}\text { New Horizon Histo- } \\
\text { ry }\end{array}$ & Theme A & $\begin{array}{l}\text { W.F. Wong, K.P. } \\
\text { Leung, Dr. W.C. Ho, } \\
\text { C.P. Chui, K.W. } \\
\text { Cheung }\end{array}$ & 2009 & $\begin{array}{l}\text { C\&A Guide } \\
2007\end{array}$ & Grade 11 \\
\hline 27 & $\begin{array}{l}\text { Hong Kong } \\
\text { Educational } \\
\text { Publishing } \\
\text { Company }\end{array}$ & $\begin{array}{l}\text { New Horizon Histo- } \\
\text { ry }\end{array}$ & Theme B & W.F. Wong & 2009 & $\begin{array}{c}\text { C\&A Guide } \\
2007\end{array}$ & Grade 12 \\
\hline 28 & $\begin{array}{l}\text { Aristo Educa- } \\
\text { tional Press Ltd }\end{array}$ & $\begin{array}{l}\text { HKDSE World } \\
\text { History in New } \\
\text { Approach }\end{array}$ & $\begin{array}{c}\text { Introduction \& } \\
\text { Theme A: Modern- } \\
\text { isation and } \\
\text { Transformation in } \\
\text { the 20th-Century } \\
\text { Asia }\end{array}$ & Rita K. L. Cheng & 2014 & $\begin{array}{c}\text { C\&A Guide } \\
2007\end{array}$ & Grade 10 \\
\hline 29 & $\begin{array}{l}\text { Aristo Educa- } \\
\text { tional Press Ltd }\end{array}$ & $\begin{array}{l}\text { HKDSE History } \\
\text { Inquiry }\end{array}$ & Vol. I & $\begin{array}{l}\text { Rita K. L. Cheng, } \\
\text { Venus S. K. Fung, } \\
\text { Nelson Y. Y. Kan, } \\
\text { Amy M. S. Lau, } \\
\text { Miranda K. L. Tang }\end{array}$ & 2009 & $\begin{array}{l}\text { C\&A Guide } \\
2007\end{array}$ & Grade 10 \\
\hline
\end{tabular}

